Joyful Learning Journal

\title{
KEEFEKTIFAN MODEL REALISTIC MATHEMATICS EDUCATION BERBANTUAN MEDIA DAKON TERHADAP HASIL BELAJAR PERKALIAN
}

\section{Erna Dwi Ratna Wati ${ }^{\bowtie}$, Elok Fariha Sari, Nugraheti Sismulyasih Sb}

Jurusan Pendidikan Guru Sekolah Dasar, Fakultas Ilmu Pendidikan, Universitas Negeri Semarang, Indonesia

\begin{tabular}{l}
\hline Info Artikel \\
\hline Sejarah Artikel: \\
Diterima Januari 2020 \\
Disetujui Februari \\
$\mathbf{2 0 2 0}$ \\
Dipublikasikan Maret \\
$\mathbf{2 0 2 0}$ \\
\hline Keywords: \\
realistic mathematics \\
education; dakon; \\
learning outcomes; \\
\hline
\end{tabular}

\begin{abstract}
Abstrak
Penelitian ini bertujuan untuk menguji keefektifan model realistic mathematics education berbantuan media dakon terhadap hasil belajar operasi hitung perkalian kelas III SDN Gugus Srikandi Gunungpati Semarang. Jenis penelitian yang digunakan yaitu quasi experimental design dengan bentuk nonequivalent control group design. Populasi pada penelitian ini yaitu seluruh siswa kelas III dari 8 SDN Gugus Srikandi. Pengambilan sampel menggunakan teknik cluster sampling atau area sampling. Sampel yang ditetapkan yaitu siswa kelas III SDN Pongangan sebagai kelas eksperimen dan siswa kelas III SDN Cepoko sebagai kelas kontrol. Teknik pengumpulan data menggunakan tes dan nontes. Hasil penelitian menunjukan peningkatan hasil belajar siswa kelas eksperimen sebesar 32,03 dan kelas kontrol sebesar 21,5. Hasil uji hipotesis menunjukan nilai thitung $(3,57)>$ tabel $(1,67)$ sehingga rata-rata hasil belajar operasi hitung perkalian kelas eksperimen lebih dari rata-rata hasil belajar operasi hitung perkalian kelas kontrol. Selanjutnya hasil n-gain kelas eksperimen sebesar 0,7003 dengan kriteria tinggi dan nilai n-gain kelas kontrol sebesar 0,4205 dengan kriteria sedang. Berdasarkan hasil tersebut dapat disimpulkan bahwa model realistic mathematics education berbantuan media dakon lebih efektif daripada model konvensional terhadap hasil belajar operasi hitung perkalian siswa kelas III SDN Gugus Srikandi Gunungpati Semarang.
\end{abstract}

\section{Abstract}

This study aimed to test the effectiveness of realistic mathematics education models assisted by the dakon media on learning outcomes of multiplication operations of $3^{\text {rd }}$ grade elementary school of Cluster Srikandi Gunungpati Semarang. This type of research is a quasi experimental design with a form of nonequivalent control group design. The population in this study were all students of $3^{\text {rd }}$ grade from 8 SDN Srikandi Cluster. Sampling used cluster sampling techniques or area sampling. The determined samples were the third grade students of Pongangan Elementary School as an experimental class and third grade students of Cepoko Elementary School as a control class. Data collection techniques used test and nontest. The results showed an increase in student learning outcomes of the experimental class by 32.03 and the control class by 21.5. Hypothesis test results showed the value of t-count (3.57)> t-table (1.67) so that the average learning outcomes of the experimental class multiplication operations is higher than the average learning outcomes of the control class multiplication operations. Furthermore, the n-gain of the experimental class was 0.7003 with high criteria and the $n$-gain value of the control class was 0.4205 with moderate criteria. Based on these results, it could be concluded that the realistic mathematics education model assisted by the media of dakon was more effective than the conventional model of learning outcomes of multiplication operations of $3^{\text {rd }}$ grade students at elementary school of Cluster Srikandi Gunungpati Semarang.

C 2020 Universitas Negeri Semarang

Alamat korespondensi:

Slatri RT 04 RW 01, Karangkobar, Banjarnegara

ISSN 2252-6366

E-mail: ernadwiratna10@gmail.com 


\section{PENDAHULUAN}

Menurut Susanto (2016:183) dengan mempelajari matematika siswa dapat belajar berfikir secara kritis, kreatif, dan aktif. Pemahaman konsep matematika di sekolah dasar sangatlah penting dan harus tertanam dibenak siswa secara kekal. Sehingga mampu menopang keberhasilan siswa dalam pemahaman konsep ditingkat yang lebih tinggi. Pemahaman konsep matematika berada pada urutan pertama dari tujuan pembelajaran matematika. Seperti halnya tujuan pembelajaran matematika yang uraikan oleh Depdiknas (dalam Susanto 2016:190) yaitu siswa dapat memahami konsep matematika, menjelaskan keterkaitan antar konsep, dan menerapkan konsep atau algoritme. Sebagian besar siswa sekolah dasar mengalami kesulitan dalam memahami materi matematika. Hal ini dipengaruhi oleh matematika yang berisikan materi bersifat abstrak. Susanto (2016:183) menjelaskan bahwa matematika merupakan ide yang bersifat abstrak berisikan simbol-simbol, sehingga sebelum memanipulasi simbol tersebut kita harus memahami konsep dasar dari matematika. Pendapat tersebut sejalan dengan penjelasan dari Priatna \& Yuliardi (2018:4) menganai ciri khas dari matematika yaitu bersifat abstrak.

Berdasarkan hasil wawancara dengan guru kelas III SDN Gugus Srikandi Gunungpati Kota Semarang, diperoleh beberapa permasalahan yang terjadi dalam proses pembelajaran matematika. Masalah yang ditemukan yaitu proses pembelajaran di SDN Gugus Srikandi masih menggunakan model pembelajaran yang bersifat konvensional. Proses pembelajaran yang didominasi oleh guru dan berpusat pada guru mengakibatkan pembelajaran kurang bermakna bagi siswa. Permasalahan selanjutnya yaitu kurangnya media pembelajaran yang disediakan oleh sekolah menjadi pemicu mengapa guru tidak pernah menggunakan media pada saat proses pembelajaran.

Adanya permasalahan-permasalahan tersebut mengakibatan siswa di SDN Gugus Srikandi mengalami kesulitan dalam memahami materi operasi hitung perkalian pada bilangan cacah yang mengakibatkan hasil belajar matematika siswa menjadi rendah. Hal tersebut didukung dengan data nilai matematika siswa kelas kelas III SDN Gugus Srikandi yang menunjukan bahwa 39\% siswa dapat melampui KKM, sedangkan $61 \%$ belummelampaui KKM. Berdasarkan permasalahan tersebut peneliti ingin menguji keefektifan model pembelajaran realistic mathematics edcation berbantuan media dakon dibangdingkan dengan model konvensional. Model realistic mathematics education berbantuan media dakon diharapkan dapat memperbaiki proses pembelajaran matematika sehingga hasil belajar siswa dapat meningkat.

Pembelajaran realistic mathematics education digagas seorang ahli matematika dari Utrect University Netherland yaitu Prof. Hans Freudenthal yang berpendapat bahwa matematika merupakan suatu aktivitas manusia (Shoimin 2014:147). Proses pembelajaran matematika harus dikaitan dengan hal-hal yang bersifat nyata atau real sesuai dengan konteks kehidupan sehari-hari siswa. Proses pembelajaran RME berpusat pada siswa. Siswa diposisikan sebagai subyek pembelajaran sehingga siswa bukan hanya sebagai penerima materi matematika yang pasif, tetapi siswa juga memiliki peluang agar dapat menemukan pengetahuan serta pemahamannya sendiri melalui praktik yang mereka alami. Peluang tersebut bertujuan untuk menciptakan pembelajaran yang beramakna bagi siswa.

Selain penggunaan model pembelajaran realistic mathematics education, media pembelajaran juga perlu digunakan guna membantu kelancaran dalam proses pembelajaran. Penggunaan media pembelajaran dapat memudahkan siswa dalam memahami konsep matematika yang bersifat abstrak. Anitah dkk. (2014:6.10) menjelaskan bahwa dengan menggunakan media pembelajaran maka siswa dapat berinteraksi secara langsung dengan lingkungannya dan dapat membangkitkan motivasi siswa untuk belajar. Media pembelajaran yang akan diterapkan yaitu media dakon. Dakon atau yang biasa disebut sebagai congklak merupakan suatu alat yang dapat dimanfaatkan guna melatih kemampuan berhitung siswa (Kurniawati, 2016:93).

Penelitian yang mendukung model realistic mahtematics education efektif dalam meningkatkan hasil belajar matematika siswa yaitu penelitian yang dilakukan oleh Pratomo dkk pada tahun 2016. Hasil penelitian yang diperoleh yaitu pendekatan RME dengan metode dril efektif terhadap hasil belajar matematika siswa kelas III. Selanjutnya penelitian mengenai media dakon oleh Ikmah, Maryadi, \& Wijayanti pada tahun 2018. Hasil penelitian yang diperoleh yaitu model pembelajaran open ended problem berbantuan media kakon berpengaruh terhadap hasil belajar matematika siswa.

Rumusan masalah pada penelitian ini yaitu: (1) Apakah model realistic mathematics education berbantuan media dakon dapat meningkatkan hasil belajar operasi hitung perkalian siswa kelas III SDN Gugus Srikandi Gunungpati Semarang?, (2) Apakah model pembelajaran realisic mathematics education berbantuan media dakon lebih efektif daripada 
model konvensional terhadap hasil belajar operasi hitung perkalian siswa kelas III SDN Gugus Srikandi Gunungpati Semarang?.

Berdasarkan rumusan masalah tersebut, tujuan penelitian ini yaitu untuk mengidentifikasi peningkatan hasil belajar operasi hitung perkalian siswa kelas III SDN Gugus Srikandi Gunungpati Semarang menggunakan model realistic mathematics education berbantuan media dakon. Serta menguji keefektifan model realistic mathematics education berbantuan media dakon dibandingkan dengan model konvensional dalam pembelajaran matematika terhadap hasil belajar operasi hitung perkalian siswa kelas III SDN Gugus Srikandi Gunungpati Semarang.

\section{METODE PENELITIAN}

Penelitian ini menggunakan metode kuantitatif dengan jenis penelitian eksperimen. Desain penelitian yang diterapkan yaitu quasi experimental design dengan bentuk nonequivalent control group design. Berikut gambaran dari nonequivalent control group design (Sugiyono, 2016:116).

\begin{tabular}{|llr|}
\hline $\mathrm{O}_{1}$ & $\mathrm{x}$ & $\mathrm{O}_{2}$ \\
\hline $\mathrm{O}_{3}$ & & $\mathrm{O}_{4}$ \\
\hline
\end{tabular}

Keterangan :

O1 : Pretest kelas eksperimen

\section{O3 : Pretest kelas kontrol}

$\mathrm{X} \quad$ : Pemberian perlakuan model pembelajaran realistic mathematics education berbantuan media dakon

O2 : Posttest kelas eksperimen

O4 : Posttest kelas kontrol

Populasi pada penelitian ini yaitu seluruh siswa kelas III dari 8 SDN Gugus Srikandi Gunungpati Semarang dengan jumlah 198 siswa. Sampel penelitian diambil dengan teknik sampling yaitu cluster random sampling. Sehingga diperoleh siswa kelas III SDN Pongangan sebagai kelas eksperimen, SDN Cepoko sebagai kelas kontrol, dan SDN Kandri sebagai kelas uji coba. Variabel bebas dalam penelitian ini yaitu model pembelajaran realistic mathematics education berbantuan media dakon dan variabel terikat yaitu hasil belajar operasi hitung perkalian siswa kelas III. Teknik pengumpulkan data menggunakan tes dan non tes. Melakukan analisis perangkat tes berupa uji validitas, reliabilitas, taraf kesukaran, dan daya pembeda soal sebelum instrumen tes tersebut digunakan dalam pengambilan data.
Teknik analisis terdiri dari analisis data awal dan analisis data akhir. Analisis data awal yaitu uji normalitas, uji homogenitas, dan uji kesamaan rata-rata dan analisis data akhir yaitu uji normalitas, ui homogenitas, uji hipotesis, dan uji n-gain. Uji hipotesis digunakan untuk mengetahui keefektifan model realistic mathematics education berbantuan media dakon terhadap hasil belajar matematika materi operasi hitung perkalian. Perhitungan uji hipotesis menggunakan uji independen sample t-test dengan bantuan ms.excel. Kriteria pengujian uji t-test yaitu $\mathrm{dk}=(\mathrm{n} 1+\mathrm{n} 2-2) \mathrm{H} 0$ diterima jika nilai thitung<ttabel (Sugiyono 2016:139). Selanjutnya uji n-gain digunakan untuk menguji peningkatan rata-rata hasil belajar matematika materi operasi hitung perkalian pada kelas eksperimen dan kelas kontrol.

\section{HASIL DAN PEMBAHASAN}

Terdapat perbedaan rata-rata nilai posttest siswa kelas eksperimen dan siswa kelas kontrol antara pembelajaran yang menerapkan model realistic mathematics education berbantuan media dakon dan pebelajaran yang menerapkan model konvensional. Dibuktikan dengan hasil rata-rata nilai posttest siswa kelas eksperimen yaitu 84,19 dan kelas kontrol yaitu 74,33. Data dari hasil belajar siswa dilakukan uji normalitas dan uji homogenitas. Uji tersebut merupakan uji pesyaratan yang harus dilakukan guna menentukan rumus yang digunakan dalam pengujian hipotesis. Berdasarkan uji normalitas menggunakan uji chi kuadrat $\left(\mathrm{X}^{2}\right)$ kelas ekspeirmen mendapatkan sebesar 7,98 dan kelas kontrol sebesar 9,27. Kedua kelas memiliki nilai $\mathrm{X}^{2}$ hitung $<\mathrm{X}^{2}$ tabel $(11,07)$ yang menunjukan bahwa data posttest kelas eksperimen dan kelas kontrol berdistribusi normal. Selanjutnya perolehan nilai signifikan hasil uji homogenitas menggunakan SPSS16 yaitu 0,087 > 0,05 yang menunjukan bahwa data posttest kelas ekspeirmen dan kelas kontrol memiliki varians yang sama atau homogen.

Setelah dilakukan uji normalitas dan uji homogenitas, selanjutnya untuk mengetahui perbedaan rata-rata hasil belajar kelas kontrol dan kelas eksperimen maka dilakukan uji hipotesis. Uji hipotesis dalam penelitian ini menunjukan bahwa model realistc mathematics education berbantuan media dakon lebih efektif daripada model konvensional terhadap hasil belajar operasi hitung perkalian kelas III SDN Gugus Srikandi Semarang. Hal tersebut dibuktikan dengan hasil uji t-test dengan bantuan ms.excel yang menunjukan nilai thitung $(3,57)>$ ttabel $(1,67)$ artinya $\mathrm{H} 0$ ditolak dan $\mathrm{Ha}$ diterima berdasarkan kriteria pengujian menurut Sugiyono (2016:139) yaitu terima H0 jika 
thitung < ttabel. Hasil uji hipotesis tersebut dapat dilihat dalam tabel berikut:

Tabel 1. Hasil Uji T-Test

t-Test: Two-Sample Assuming Equal Variances

Rata- Variansthitung $P$-value ttabel rata

Posttest

\begin{tabular}{|c|c|c|}
\hline & Posttest & \\
\hline Kelas & $74,33 \quad 159,89$ & \\
\hline $\begin{array}{c}\text { Kelas } \\
\text { Eksperimen }\end{array}$ & $84,19 \quad 99,32$ & $33,57 \quad 0,0003 \quad 1,67$ \\
\hline
\end{tabular}

Hasil penelitian ini sejalan dengan penelitian yang dilakukan oleh Laurens, $t$, dkk pada tahun 2017 yang menunjukan bahwa hasil belajar siswa dengan menerapkan model RME lebih baik dibandingkan dengan hasil belajar siswa model konvensional. Dibuktikan dengan hasi uji t-test yang memperoleh nilai thitung $(3,320)>$ ttabel $(1,6772)$.

Penelitian yang dilakukan oleh Taubah, Isnarto, \& Rochmad pada tahun 2018 yang menunjukan bahwa model realistic mathematics education efektif terhadap kemampuan berpikir kritis matematika siswa. Hal tersebut sejalan dengan penelitian yang dilakukan oleh Karyadi, dkk pada tahun 2018 yang memperoleh hasil bahwa pembelajaran RME efektif terhadap kemampuan literasi matematika siswa. Penelitian mengenai media dakon yang dilakukan oleh Wahyu, A. pada tahun 2018 yang menunjukan bahwa terdapat peningkatan aktivitas siswa dan hasil belajar siswa setelah diterapkannya permainan dakon dalam proses pembelajaran. Selanjutnya penelitian yang dilakukan oleh Sari, dkk pada tahun 2019 menunjukan bahwa media dakonmatemaika berpengaruh terhadap kemampuan pemecahan masalah matematika.

Selanjutnya uji n-gain dilakukan guna mengetahui perbedaan peningkatan hasil belajar operasi hitung perkalian siswa. Peningkatan rata-rata nilai yang diperoleh siwa kelas eksperimen yaitu 32,03 lebih tinggi dibandingkan dengan siswa kelas kontrol yaitu 21,5. Nilai n-gain kelas eksperimen yaitu 0,7003 dengan kriteria tinggi, sedangkan nilai n-gain kelas kontrol yaitu 0,4205 dengan kriteria sedang. Berdasarkan hasil pretest dan posttest dengan perhitungan tersebut menunjukkan bahwa siswa kelas eksperimen dengan penerapan model realistic mathematics education berbantuan media dakon memiliki peningkatan hasil belajar lebih tinggi daripada siswa kelas kontrol yang menggunakan model konvensional.
Hasil uji n-gain tersebut dapat dilihat pada tabel berikut:

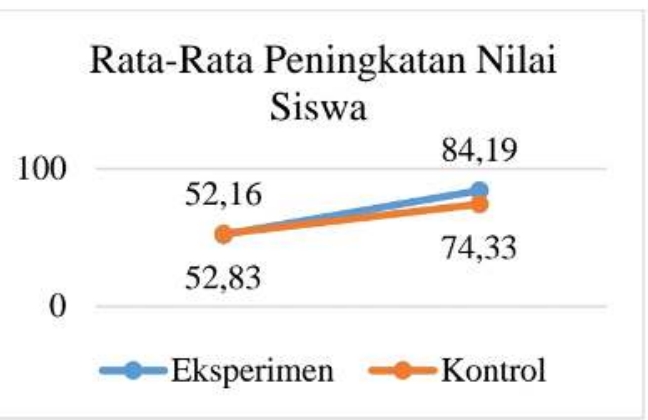

Gambar 1. Diagram Peningkatan Rata-Rata Hasil Belajar Matematika Materi Operasi Hitung Perkalian Kelas III SDN Gugus Srikandi

Hasil penelitian ini relevan dengan penelitian yang dilakukan oleh Tanjung, H.S pada tahun 2019 yang menunjukan bahwa model realistic mathematics education dapat meningkatkan kemapuan pemahaman dan prestasi belajar siswa. Hal tersebut sejalan dengan penelitian dari Agus R. N pada tahun 2016 yang memperoleh hasil bahwa penerapan pendekatan RME dengan pemecahan masalah efektif untuk meningkatkan prestasi belajar siswa.

Penelitian yang dilakukan oleh Nataliya, P. pada tahun 2015 yang menunjukan bahwa terdapat peningkatan kemampuan berhitung siswa dengan menerapkan permainan tradisional congklak. Penelitian yang dilakukan oleh Noviyanti, Sumarno \& Subekti pada tahun 2017 yang menunjukan bahwa model pembelajaran Talking Stick berbantuan media dakon matematika efektif terhadap pemahaman matematika siswa. Berdasarkan hasil tersebut, dapat disimpulkan bahwa pembelajaran dengan menerapkan model realistic mathematics education berbantuan media dakon dapat meningkatkan hasil belajar operasi hitung perkalian dan model pembelajaran realistic mathematics education berbantuan media dakon lebih efektif daripada model konvensional terhadap hasil belajar operasi hitung perkalian.

\section{SIMPULAN}

Berdasarkan hasil penelitian dan pembahasan dapat disimpulkan bahwa hasil perhitung uji t-test memperoleh nilai thitung $(3,57)>$ ttabel $(1,67)$, yang artinya H0 ditolak dan $\mathrm{Ha}$ diterima. Sehingga model realistic matematics education berbantuan media dakon lebih efektif daripada model konvensional terhadap hasil belajar operasi hitung perkalian kelas III SDN Gugus Srikandi Gunungpati Semarang. Selanjutnya berdasarkan uji n-gain diperoleh peningkatan rata-rata kelas eksperimen yaitu 32,03 dan peningkatan rata- 
rata kelas kontrol yaitu 21,5 . Untuk nilai n-gain kelas eksperimen yaitu 0,7003 dengan kategori tinggi, sedangkan kelas kontrol yaitu 0,4205 dengan kategori sedang. Sehingga model realistic mathematics education berbantuan media dakon dapat meningkatkan hasil belajar operasi hitung perkalian kelas III SDN Gugus Srikandi Gunungpati Semarang.

\section{UCAPAN TERIMAKASIH}

Penulis mengucapkan terima kasih kepada SDN Gugus Srikandi Gunungpati Semarang yang telah membantu dalam pelaksanaan penelitian, sehingga peneliti dapat menyelesaikan masnuskrip ini.

\section{DAFTAR PUSTAKA}

Agus, R.N. 2016. Efektivitas Pembelajaran Matematika melalui Pendekatan Realistic Mathematics Education (RME) dengan Pemecahan Masalah ditinjau dari Gaya Belajar Siswa. JIP JTKP Kusuma Negara. 7(2) 77-90.

Anitah, S., dkk. 2014. Strategi Pembelajaran di SD. Tangerang Selatan: Universitas Terbuka.

Ikmah, Maryadi, \& Wijayanti. 2018. Pengaruh Model Pembelajaran Open Ended Problem Berbantu Media Kalkulator Dakon (Kakon) terhadap Hasil Belajar Matematika Siswa Kelas II SDN Sambiroto $01 \mathrm{Kec}$. Tembalang Kota Semarang. Jurnal Guru Kita (JGK). 2(3):126-133.

Karyadi, Suyitno, \& Dwidayanti. 2018. Analisis The Ability of Students Mathematical Literacy on The Realistic Mathematics Education Learning with The Loads of The Character of Islam. Unnes Journal of Mathematics Education Research. 7(1):18-25.

Kurniati, Euis. 2016. Permainan Tradisional. Jakarta: Prenadamedia Group.

Laurens, T, dkk. 2017. How Does Realistic Mathematics Education (RME) Improve Students' Mathematics Cognitive Achievemnt. EURASIA of Mathematics Science and Technology Education. 13(-):1-12.

$\begin{array}{ccr}\text { Nataliya, P. 2015. } & \text { Efektivitas } & \text { Penggunaan } \\ \text { Media } & \text { Pembelajaran } & \text { Permainan } \\ \text { Tradisional } & \text { Congklak } & \text { untuk } \\ \text { Meningkatkan } & \text { Kemampuan } & \text { Berhitung }\end{array}$ pada Siswa Sekolah Dasar. Jurnal Ilmiah Psikologi Terapan. 3(2): 343-358

Noviyanti, Sumarno, \& Subekti. 2017. Keefektifan Model Pembelajaran Talking Stick dengan Media Dakon Matematika terhadap Pemahaman Konsep Matematika Siswa Kelas IV SD. Jurnal Sekolah (JS). 2(1) 112-115

Pratomo, W. H., Ysh, Soegeng, \& Rahmawati, I. 2016. Keefektifan Pendekatan Realistic Mathematics Education dengan Metode Dril terhadap Hasil Belajar Matematika Siswa Kelas III SD. Profesi Pendidikan Dasar. 3(2):141-147.

Priatna, N \& Yuliardi, R. 2018. Pembelajaran Matematika. Bandung: PT Remaja Rosdakarya.

Sari, Saputra, \& Azizah. 2019. Penerapan Model Numbered Heads Together Berbantu Dakonmatemaika Pada Kemampuan Pemecahan Masalah Matematika. Jurnal Ilmiah Sekolah Dasar. 3(1):51-56.

Shoimin, Aris. 2014. 68 Model Pembelajaran Inovatif. Yogyakarta: Ar-Ruzz Media.

Sugiyono. 2016a. Statistika untuk Penelitian. Bandung: Alfabeta

Susanto, Ahmad. 2016. Teori Belajar \& Pembelajaran. Jakarta: Prenadamedia Grup

Tanjung, H.S. 2019. Penerapan Model Realistic Mathematics Education (RME) untuk Meningkatkan Pemahaman Konsep dan Hasil Belajar Siswa.-. 6(1):101-112.

Taubah, Isnarto, \& Rochmad. 2018. Student Critical Thingking Viewed from Mathematical Self-Efficacy Means End Analysis Learning with the Realistic Mathematics Education Approach. Unnes Journal of Mathematics Education Reseacrh. 7(2):189-195

Wahyu, A. 2018. Peningkatan Aktivitas dan Hasil Belajar Matematika Siswa Kelas I SDN Pesantren Tembelang Jombang melalui Permainan Dakon. Jurnal Program Studi Pendidikan Matematika. 6(2):60-68 